\title{
Working with the students a multiprofessional care environment: a psychodrama experience*
}

\author{
Trabalhando com estudantes um ambiente multiprofissional de \\ cuidado: uma experiência com psicodrama
}

\author{
lêda Aleluia', Ana Lúcia Barbosa Góes², Ubton José Nascimento³ \\ 'Corresponding author. BAHIANA - School of Medicine and Public Health, Salvador, Bahia, Brazil. \\ ORCID: 0000-0002-7979-1938. iedaleluia@bahiana.edu.br \\ 2BAHIANA - School of Medicine and Public Health, Salvador, Bahia, Brazil. ORCID: 0000-0003-2486-0876. albgoes@bahiana.edu.br \\ ${ }^{3}$ BAHIANA - School of Medicine and Public Health, Salvador, Bahia, Brazil. ORCID: 0000-0003-3031-2702. ubtonjose@gmail.com
}

RESUMO I CONTEXTO: Uma oficina foi oferecida para estimular estudantes da saúde a ter uma perspectiva humanística do paciente. RESUMO DO TRABALHO: 03 professores prepararam uma oficina para discutir o cuidado e o trabalho multiprofissional na saúde, usando a base do psicodrama. RESUMO DOS RESULTADOS: 14 estudantes participaram. Eles expressaram seus sentimentos e criaram cenas inspiradas nos extratos de dilmes que foram exibidos. Uma das cenas foi refeita após a discussão. Os estudantes ficaram surpresos positivamente com a oficina. Nossos resultados mostraram que o sentiment principal que emergiu foi Empatia, e eles for a sensibilizados pela falta de humanidade quando trabalhamos mecanicamente. LIÇÕES APRENDIDAS/CONCLUSÕES: Essa abordagem com estudantes da saúde, precocemente e em diferentes momentos dos cursos, pode formar um professional reflexive e capaz de trabalhar em equipe, com métodos ativos e fazer diferença no seu treinamento professional.

PALAVRAS-CHAVE: Educação médica. Cuidado em saúde. Empatia. Psicodramas.

\begin{abstract}
BACKGROUND: A workshop was carried out to stimulate in the health-student a humanistic perspective on patient care. SUMMARY OF WORK: Three teachers prepared a workshop to discuss care and multiprofessional work in health, using the psychodrama framework. SUMMARY OF RESULTS: 14 students participated. They expressed their feelings and performed scenes based on movie clips that were showed to them. One of these scenes was remade after discussion. They were positively surprised with the workshop. Our results showed that the principal feeling that emerged was Empathy, and they were touched by the lack of humanity when we do our work mechanically. LESSONS LEARNED/ CONCLUSIONS: This kind of approach with the health students early and at different moments in their courses, can create a reflexive professional capable of working in a multiprofessional team with active methods and can make a difference to their training as professionals.
\end{abstract}

KEYWORDS: Medical education. Health care. Empathy. Psychodrama.

*Artigo incialmente apresentado no AMEE 2017/Paper initially presented to AMEE 2017. 


\section{Background situation}

In our school, we have an annual event that involves cultural and scientific subjects focused on student development: Mostra Cultural e Científica/Cultural and Scientific Event. For the 2017 edition, we proposed a workshop based on a multidisciplinary approach, aiming to engender, early in the health-student life, a humanistic perspective toward patient care.

\section{Summary of work}

Three teachers, with different professional qualifications (medicine, physiotherapy, psychology), offered a workshop to discuss care and multiprofessional work in health. The workshop had two parts: the first one was about feelings and perceptions which emerged after watching 03 movie clips as a trigger for discussion. We choose 02 parts of a Brazilian movie about mental health called Bicho de Sete Cabeças and we showed a short film (A Mala/ The Suitcase) made by students on the psychology course, who kindly gave their permission to use it and which deals with human nature. In the second part of the workshop, the students had a chance to create a new scene based on the feelings that had emerged, promoting other scenarios, speeches and outcomes for problems addressed by the clips, based on psychodrama theory'. They discussed this phase, looking for new ideas. At the end, they answered a survey about their perception of the workshop.

\section{Summary of results}

14 students participated. 01 from nursing, 02 from dentistry, 04 from physiotherapy, 07 from psychology; none from medicine. They expressed feelings of confusion, distress, anger, disquiet as well as feelings of identification after watching the clips. After the group presentations, they felt that one scene had to be remade and the concepts of "listening to others" and "empathy" were strengthened. Students evaluated the workshop as "surprising" in a positive way.

They used the following words and sentences, to express their feelings during the workshop:

reflection about how be in the place of other person; sorrow; conflict of feelings and emotions; perception

of limits; mess; thankful; love and care; empathy;

touched; empathy; heart touching; learning beyond

the book; wonderful experience; great reflection; clarification; good surprise; profitable; fun; wonderful and different; capacity for change; put yourself in the other person's shoes.

We put them in a cloud, created from the site tagul.com (a free use site), to demonstrate the most prevalent words present in their reflections (Figure 1):

Figure 1. Cloud of words from the students' reflection

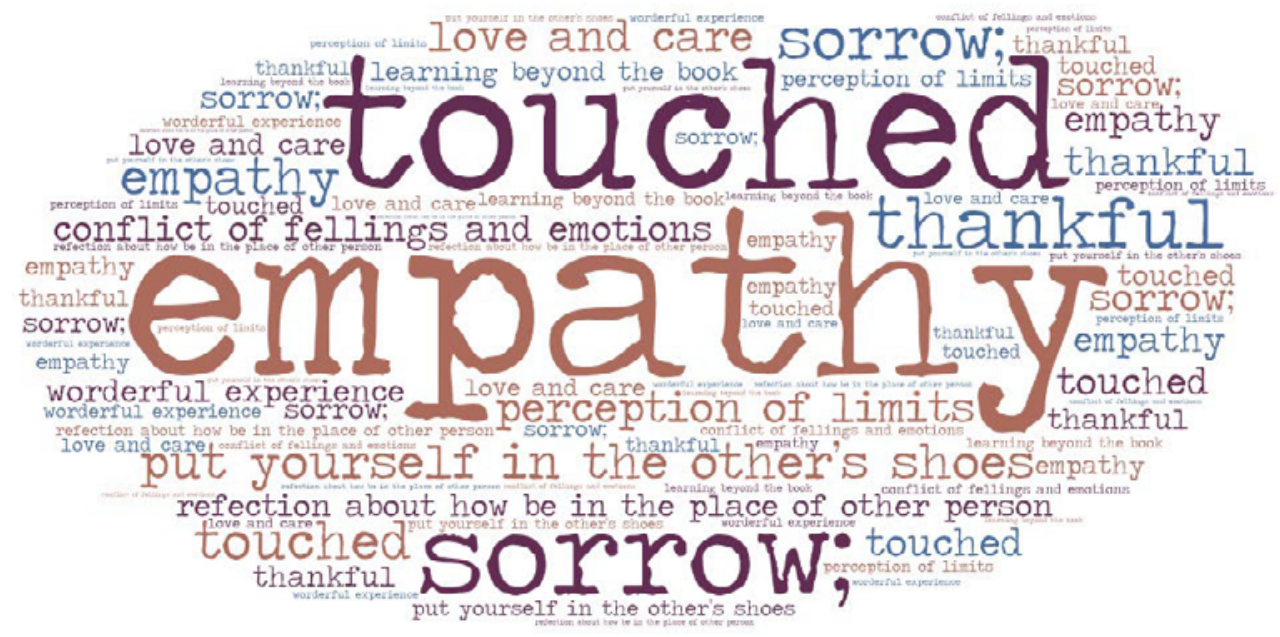


Students evaluated the workshop as "surprising" in a positive way. They did not expect this approach using the psychodrama method, and thought that it would be an ordinary class. The three different teachers' backgrounds also surprised them; they expected only teachers from psychology.

It was possible to see how the emotions and feelings circulated within the group. Students put themselves in their colleagues' shoes; they got involved in the process, confirming that empathy can be a good ingredient in interpersonal and interprofessional relationships.

The reality in hospitals and clinics demands early exposure to multiprofessional formation. This group, with no medical students, in a workshop focused on patient care opened the discussion about other means of care in health, far beyond the care that each discipline brings. The absence of medical students in this workshop was noticeable, and this became a topic of discussion. Why were the medical students not there? Was the theme not important to them? Do they not need this kind of training and reflection about care and teamwork? Other studies show that it is very important for health professionals to work together as a team, and have a humanistic approach to patients and their families ${ }^{2}$. Our results showed that the principal feeling that emerged was Empathy, and that they were touched by the lack of humanity present when we do our work mechanically; when they do not see the individual as a person.

\section{Lessons learned/ Conclusions}

Students need more time during their graduate courses to work within the multiprofessional dimension. They expressed the need to develop a new outlook in this field, having another person as a mirror. Medical students should be encouraged to attend workshops like this to develop humanistic behavior.

This kind of approach to health students early and at different times on their courses can create a reflexive professional capable of working in a multiprofessional team with an active methodology.
We think that this approach will make a difference in the development of humanistic medical role.

\section{Authors contribution}

Aleluia I participated in the conception of work, data collection, data analysis, writing and manuscript submission. Góes ALB participated in the conception of work, data collection, writing and article review. Nascimento UJ participated in the conception of work, data collection, writing and article review.

\section{Competing interests}

No financial, legal or political competing interests with third parties (government, commercial, private foundation, etc.) were disclosed for any aspect of the submitted work (including but not limited to grants, data monitoring board, study design, manuscript preparation, statistical analysis, etc.).

\section{Reference}

1. Motta KAMB, Munari DB, Leal ML, Medeiros M, Nunes FC. As trilhas essenciais que fundamentam o processo e desenvolvimento da dinâmica grupal. Rev Eletr Enf. $2007 ; 9(1): 229-41$.

2. Liberali R, Grosseman S. Use of Psychodrama in Medicine en Brazil: a review of the literature. Interface. 2015;19(54):561-71. doi: 10.1590/1807-57622014.0524

3. Abrianda. Tagul [Internet]. Disponível em: https://wordart. $\mathrm{com} / \mathrm{mxkrsu} 7 \mathrm{k} 4 \mathrm{fkv} / \mathrm{tagul}$ 